\title{
Employers expectations and requirements. Case study: Employers of Schools of Economics and Business Graduates in Romania
}

\author{
Camelia STAICULESCU \\ Bucharest University of Economic Studies, Bucharest, Romania \\ camelia.staiculescu@dppd.ase.ro \\ Maria Liana LACATUS \\ Bucharest University of Economic Studies, Bucharest, Romania \\ maria.lacatus@dppd.ase.ro \\ Raluca LIVINTI \\ Bucharest University of Economic Studies, Bucharest, Romania \\ raluca.livinti@ase.ro
}

\begin{abstract}
Nowadays, employers are reconsidering the definitions of professionalism and professionals. In addition to job related knowledge and skills, a professional need some general behavioral skills too, which are especially required when working with others. These inter-relational skills are not "hard skills", but "soft skills" Being challenge to face an economic reality that is changing permanently, universities have to adapt themselves and to respond to the needs of the socio-economic environment by developing and adapting their educational services to the contemporary requirements. Among the multiple dimensions of the changes universities are facing nowadays important ones are the changes at the curriculum level: goals consisting in competences according to the labor market requirements, new educational plans and programs, new content and teaching and learning strategies, new learning settings and environments. The paper presents the experts' perspective in respect with the ways in which universities are developing and innovating their curricula and analyses Romanian employers' opinions regarding the curriculum development and innovation in schools of economics and business. The analysis is based on a survey conducted among the most important employers in Bucharest, the capital city of Romania and, in the same time, the largest local labor market in the country with national and multinational companies. Recommendations regarding the curriculum development and innovation are included too. These are meant to enhance the capacities of universities to provide high quality education and develop competences required on the labor market.
\end{abstract}

Keywords: employability, university graduates competences, work experience, employers' requirements and expectations.

\section{Introduction}

The university graduates' employability represents an interesting issue both for universities and employers. Nowadays, the labor market is extremely dynamic. It is the place where university graduates have the opportunity to demonstrate their knowledge and competences and to meet the employers' requirements regarding their professional and transversal competences.

Understanding and meeting the employers' requirements have consequences on the educational policies of the universities and affect their relationships with the students, graduates, communities and labor market. Among others changes universities have to accept are the challenge to prepare students for a future in which the jobs exiting today will be replaced by new jobs in new business activities. They have to be ready to a shift from present to future, from

DOI: $10.2478 /$ picbe-2021-0018

(C) 2021 C. Staiculescu, M. L. Lacatus, R. Livinti, published by Sciendo.

This work is licensed under the Creative Commons Attribution 4.0 License. 
existing situations to changes, certainty to uncertainty. These imply a new perspective on education and new models of curriculum, nonlinear and probabilistic, that prepare students to deal with the uncertainty of the future (Bratianu, Hadad and Bejinaru, 2020).

Universities are under a great pressure due to the public debates regarding the types of competences they have to develop to students. Employers' expectations in respect with the university graduates are higher in comparison with other categories of employees.

The orientation of universities to employers' expectations is part of the efforts made nowadays by higher education institutions to provide education for sustainable development and help create a more sustainable future (Blessinger et al., 2018). As one the most important knowledge producers in the society, universities have to provide knowledge and competences that future professionals, thinkers and decision makers need to act in sustainable ways. Among others changes universities have to accept are nonlinear competences-based curriculum and probabilistic models of learning that prepare students to deal with the uncertainty of the future (Bratianu, Hadad and Bejinaru, 2020).

They are called to develop a system of values that emphasizes responsibility to the future and to the others and to promote these values not only among students, but among all the people they can rich.

Employers are expected from their future employees to demonstrate professional knowledge and competences and also proper attitudes towards work, creative and critical thinking, and crucial values such as responsibility, accountability or commitment.

First of all, they expect from university graduates to have an in-depth understanding of the work environment, the capacity to apply the knowledge they gained at university and to demonstrate a competitive advantage in the labor market (Clarke, 2017).

\section{Literature review}

Regarding the key competencies necessary for a good socio-professional integration of people, one can see that there are many debates in the literature today, both schools / universities and employers trying to describe the desirable profile of the graduate / employee in terms of personality structure and behaviors that meet expectations.

There are mainly two main types of skills: professional skills or so called hard skills, which are required to effectively perform different professions and transversal skills or soft skills which help people to be adaptable, open to change, able to mobilize their internal resources in order to successfully cope with challenges of any kind.

Succi and Canovi (2019) describe soft skills as "a set of cognitive and meta-cognitive skills, interpersonal, intellectual and practical skills useful for graduates in the context of labor market challenges", necessary for jobs in various economic sectors but also for greater adaptability and productive involvement of one person within the company.

Finch et al. (2013), make a synthesis and a hierarchy of skills and factors that are considered relevant for employers in the case of graduates, as following:

- Soft skills - represented by those non-academic skills that are considered relevant in the employment stage and during the professional life: verbal and written communication skills, listening skills, professionalism or teamwork ability;

- Problem-solving skills that involve "the ability to make decisions, analysis and synthesis, without applying them in a mechanical manner", but customized to the type of situation encountered. This ability involves: critical thinking, creativity, leadership skills, adaptability; 
- Job-specific skills that require knowledge about certain information needed to work in a particular field;

- Work experience prior to graduation, acquired by graduates during internships or in temporary jobs;

- The academic reputation of the institution measured by the perception that employers have towards different higher education institutions or towards the university curriculum.

The inventory of soft skills in the literature shows us a diverse range of approaches.

PICBE |

187 Suarta et al. (2017) show that employers appreciate skills such as: critical and analytical thinking, creativity and innovation, the ability to synthesize information, solve problems, collaborate, communicate, work in teams, and learn. In employers 'opinion these skills are important both for first job employment and for professional development in case of employed people.

Surveys conducted among employers in European countries such as Romania or Italy show that employers expect that future employees have abilities and skills not necessarily related to professional qualification but to personality and character development and education (Staiculescu et al., 2018; Succi and Canovi, 2019). They expect from employees to know themselves very well and have a realistic image of what they are and what they want to become, to have ethical and responsible professional behaviors and the desire to develop themselves both professionally and personally. Employers value qualities such as openness and availability to learn and also abilities such as communication, work in teams, problem solving, critical and innovative thinking together with the ability to take responsibilities. They think that such kind of qualities and abilities are very important for first employment.

Other surveys show that employers' expectations towards university graduates are higher compared to those towards other categories of employees (Clarke 2017). In employers' opinion, the educated employees have a competitive advantage on the labor market given by knowledge acquired in universities. But, this advantage has to be proven by an in-depth understanding of the environment in which they will work and the ability to put into practice the knowledge acquired.

The analysis of these perspectives shows us that there is a set of soft skills pointed out by researchers and skills included in this set of skills can be divided into two categories: personality traits related skills (critical thinking, creativity and innovation, the ability to solve problems, self-knowledge and desire for development, adaptability, etc.) and socio-professional behaviors and attitudes related skills (responsibility, work in teams, ethical behavior, communication, etc.).

However, beyond the description and inventory of these soft skills, there is the issue of the connection between them and the ethical dimension of social and professional behavior. Any professional behavior includes ethical issues too. In some cases, such as the case of employers in Romania (Staiculescu et al., 2018), ethical professional behaviors and attitudes are mentioned as being desirable, but not described and analyzed.

On the one hand values and moral principles internalized by each individual which dictate his social behavior and on the other hand a set of norms, moral rules that we must obey in social, personal and professional relationships. Organizations / employers usually state a set of ethical rules that employees need to adhere to. Thus, in the documents governing organizational behavior we find principles / norms such as: impartiality, non-discrimination, honesty, avoidance of conflict of interest, confidentiality, valorization of human resources, transparency in decision making, commitment, loyalty to the organization, social responsibility, show respect to the environment and protect it, etc. 
Employees are required to behave ethically: avoid conflicts of interest, and receiving gifts / bribes and unjust benefits, report irregularities, maintain confidentiality, respect customers, partners, competitors, etc. Speaking of attitude, it is wanted from employees to be: committed, loyal, hard-working, professional, and responsible.

The existence of those qualities at the employees is largely dependent on their soft skills. For example, respect for diversity and others is manifested in teamwork, in assuming and delegating responsibilities; critical thinking in manifesting in the interpretation and involvement in activities, in the appropriate solving of work tasks, in the proper communication with others.

Other research shows the importance of soft skills for graduates' employability and their ability to work. In a research conducted among university graduates and employers in Italy and Germany, Succi and Canovi (2019) have discovered that in the process to find a job the main issue for graduates is to prove that they have cognitive and meta-cognitive abilities, interpersonal, intellectual and practical abilities useful to face the challenges on the labor market, to move along different industries and to be productive involved in the company; in other words, to demonstrate that they have soft skills. Among soft skills are mentioned communication skills and team work, problem solving skills, critical and innovative thinking, lifelong learning skills and capacity to take responsibilities.

In a research conducted in Canada, Chhinzer and Russo (2018) aimed to identify the factors that help employers to have a positive attitude towards university graduates that successfully completed practical stages in their companies (in Canada such practical stages are compulsory for university students). Among other important findings, the above mentioned authors indicated that employers are positively influenced if they identify to students competences such as quality of work, interest, initiative, organization and planning skills, dependability and response to supervision. Employers appreciate also soft skills such as written and verbal communication, adaptability, leadership, problem solving skills, and what authors have labeled as continuous learning skills. Last but not least, employers appreciated more general skills such as time management skills, team work, professional behavior, commitment and availability to work.

The type of competences valued by employers to university graduates may vary from an industry to another. In a quantitative research conducted among 370 employers from UK, Hesketh (2000), identified a general appreciation and ranking of graduates' competences. All employers evaluate positively verbal and written communication skills, learning skills, problem solving skills, team work, organization, numeracy and ITC skills.

But, employers ranked differently competences demonstrated by the graduates they have employed. First of all, in institutions, employers appreciate digital competences, capacity to learn, numeracy and problem solving skills. Employers from informatics and computers industry tend to put more emphasis on verbal communication skills, problem solving skills and ITC skills. In sciences and engineering-based industries competences such as problem solving, numeracy, ITC, or work team are appreciated together with capacity to learn.

Employers consider to be relevant together with competences demonstrated by graduates at first job but also the university they have graduated. This is a sort of "professional identity card" of graduates due to the history and prestige of the university and previous experiences employers have had with particular university graduates.

Succi and Canovi (2019) research showed that employers form Italy and Germany consider that graduates are not properly prepared to work. One important cause might be insufficient exposure of university students to real world through practical stages and internships. 
In a research conducted at Griffith University among university students, Crebert et al. (2007), were interested to analyze universities graduates' and employers' opinion regarding the impact of practical stages on their employability. The research was conducted on university students who have participated at one practical stage or internship during their university studies. Among other conclusions, was the idea that university helped students to develop verbal and written communication skills, critical analysis and evaluation skills, problem solving and collaboration skills developed mainly by participating in activities based on team-work. Graduates considered that university could improve its educational programs and increase the quality of education by increasing the number of practical activities and internship opportunities, asking students to make more oral presentations, write papers and work to specific projects.

Griffin and Coelhoso (2018) have interviewed a group of female students from United Arab Emirates who have participated to an 8 weeks practical stage compulsory to successful graduate the university. They all appreciated that the practical stage helped them to develop the capacity to work in teams and to communicate (they had to make oral presentations and to take part in debates). These were considered key work competences. Students also express regrets that other important competences such as time management or self-management were less developed.

Moorea and Morton (2015) show that practical stages and internships ensure a good understanding of work organizations, especially when real world situations are difficult to be standardized and each organization has its own culture, requirements and standards that can be learned effectively through direct interaction and involvement within the company. However, it is important for universities to know the areas of activity in which their own graduates are employed and to expose students to complementary practices.

Wickramasinghe and Perera (2010) consider that the main activities recommended to increase the graduates' employability are changes in curriculum, professional training, and job fairs. A more recent research conducted in Romania demonstrates that in order to effectively change the curriculum universities should be open to curriculum co-creation by working together with students, graduates, and employers and among highly valued skills and attitudes are problem-solving and motivation (Bratianu, Hadad and Bejinaru, 2020).

Our paper presents more arguments in favor of a value-oriented university curriculum in order to develop soft skills and competences together with professional competences to students and to prepare them as responsible future professionals.

\section{Methodology}

\section{Research context}

Nowadays, the Bucharest University of Economic Studies (ASE) is the largest economic university in Romania and South Europe too, including 11 schools of economics and business with around 22,000 students (Table 1) enrolled in 24 bachelor programs delivered in Romanian, English, French or German languages, 89 master programs, and 10 doctoral programs studying management, accounting, marketing, finance, cybernetics and economic informatics, public administration, etc.

ASE declared mission is to develop high level of professional competences in the field of business and administration. 
Table 1. The number of students enrolled at the Bucharest University of Economic Studies

\begin{tabular}{|c|c|}
\hline University year & Students enrolled \\
\hline $2013-2014$ & 21.316 \\
\hline $2014-2015$ & 21.343 \\
\hline $2015-2016$ & 21.865 \\
\hline $2016-2017$ & 22.032 \\
\hline $2017-2018$ & 21.981 \\
\hline
\end{tabular}

Source: www.ase.ro.

A research conducted in 2017-2018 on bachelor programs graduates (Staiculescu et al., 2018) shows that $83 \%$ of ASE graduates were employed and $46 \%$ of them have jobs in the fields of their specializations while $29 \%$ of them have job in related domains. The same research shows a better situation among master programs graduates: $54 \%$ of them have jobs in the fields of their specializations while $30 \%$ of them have job in related domains.

These data show that ASE graduates are appreciated by employers. We have to mention that nowadays, in Romania there is a deficit on the labor market and employers are in competition for the best university graduates.

Students have to participate in compulsory two one-semester practical stages, first stage during bachelor program and the second one, during master program. If a student has a job in this time (could be part time or full time job) this would be an equivalent of one practical stage if the job is in the field of student's specialization. For many students to work while attending university programs is a regular situation, fact confirmed by above mentioned the research: $52 \%$ of graduates declared that they had the first job while attending courses at university or in the first 6 months after graduation.

The university helps students to find a job and be professionally integrated through good practices developed in time. Such practices are:

- Practical compulsory stages included into curriculum;

- Experts from business sector involved in teaching activities;

- Job fairs and meeting with employers representatives;

- Employers representatives involved in decision making processes in university (as members of consultative councils);

- Programs and projects conducted in partnership with employers;

- Free counselling and career orientation services for ASE graduates;

- Practical stages and internships in companies;

- Periodical research on employers' opinion regarding the quality of education provided by ASE;

- Scientific events and students contest organized in partnership with employers;

- ASE representatives are taking part in public debates on university graduates' employability and educational policies.

We consider that ASE has an open and cooperative attitude toward employers and employers' representatives and develop a pro-work educational culture.

\section{Methods and procedures}

In year 2019, we have conducted a research among employers in order to identify their perceptions on ASE graduates competences and criteria they use to employ different candidates. 
We wanted to identify the employers' expectations regarding the future employees and how close are ASE graduates to meet these expectations.

We have use a questionnaire-based survey. The questionnaire included 13 questions (12 questions with multiple choices including "others" as possible answers and 1 open question). Respondents were asked to evaluate the probability of their possible answers. Only answers with high level of probability were accepted as given answers.

The questionnaires were filed on-line in a Google format.

The questionnaires were sent by email to all employers from ASE data base in September-October 2019.

The employers group included 677 persons. Only 80 of them respond to the questions (12\% response rate). Among the respondents, 76 were representatives of private companies in different industries (finance, services and production) and 4 were representatives of public institutions. The representatives were CEOs, directors, human resource people, managers, and administrators. All of them have been involved in recruiting and selecting processes of entry level personnel with university diploma.

\section{Results and discussions}

One of the first questions asked participants to evaluate the importance of 20 criteria (each of these were personal characteristics/traits or qualities) for selecting a person for an entry level position in the company. Below (Figure 1) are the answers:

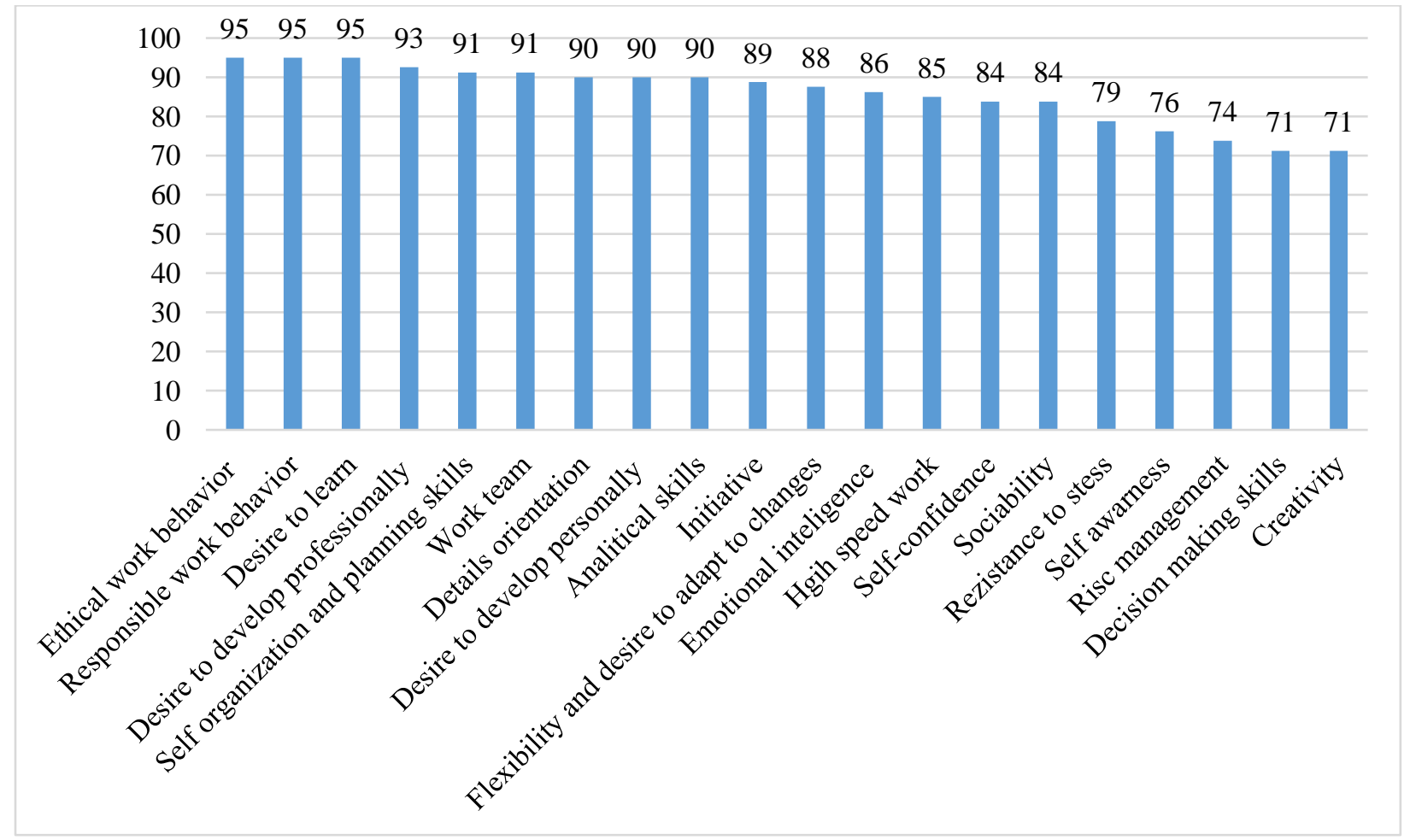

Figure 1. Personal traits highly appreciated by employers

Source: Authors' own research.

According with the data presented above, employers appreciated different traits that can be defined as commitment and responsibility to work. From employers perspective it is important 
for employees to have an ethical and responsible behavior, together with the desire to learn and to develop professionally, be able to organize and plan their own activity. These characteristics are important for more than $90 \%$ of respondents when evaluating a candidate.

Less appreciated, but with very high percentages too, are characteristics usually required for top-management employees, not in entry level positions. Among these are resistance to stress, the ability to handle borderline situations and decision making skills. On the very last position, creativity was considered one of the less important criteria, most probable due to the fact that the employees on entry level positions have to perform punctual and procedural tasks.

Among "Other" criteria, respondents have mentioned communication skills, focused on client, public image, patience, being serious, punctuality, intrapreneurship, oral presentation skills.

Another question asked respondents to evaluate the importance of competences, skills, knowledge and experience for an ASE graduate who is searching a job. Below (Figure 2) we are presenting respondents answers.

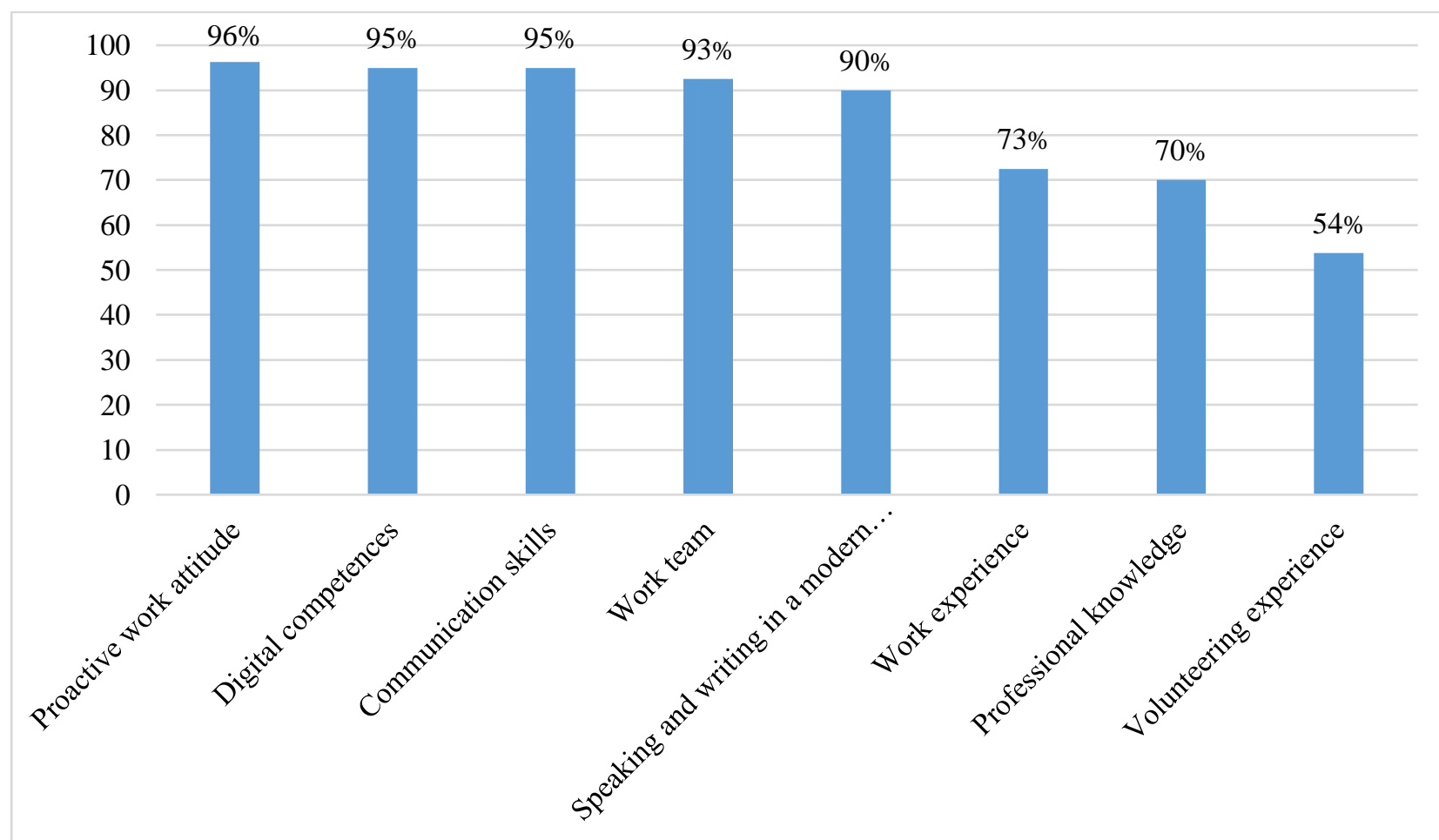

Figure 2. A ranking of competences, skills, knowledge and experience for an ASE graduate who is searching a job

Source: Authors' own research.

There are some very important competences and skills highly appreciated by employers. First of all, employers appreciated the proactive work attitude. Very important are also digital, communication and teamwork skills which are considered key competences for many employees. Employers seems to consider less important the work or volunteering experience but appreciate a good (above average) professional knowledge.

Asked to evaluate the quality of ASE graduates based upon direct interactions with them, employers considered that ASE graduates are opened to new learning experiences, show respect 
to work and specific activities of the companies (Figure 3). In the same time, they are well prepared - above the average - and have a good work attitude.

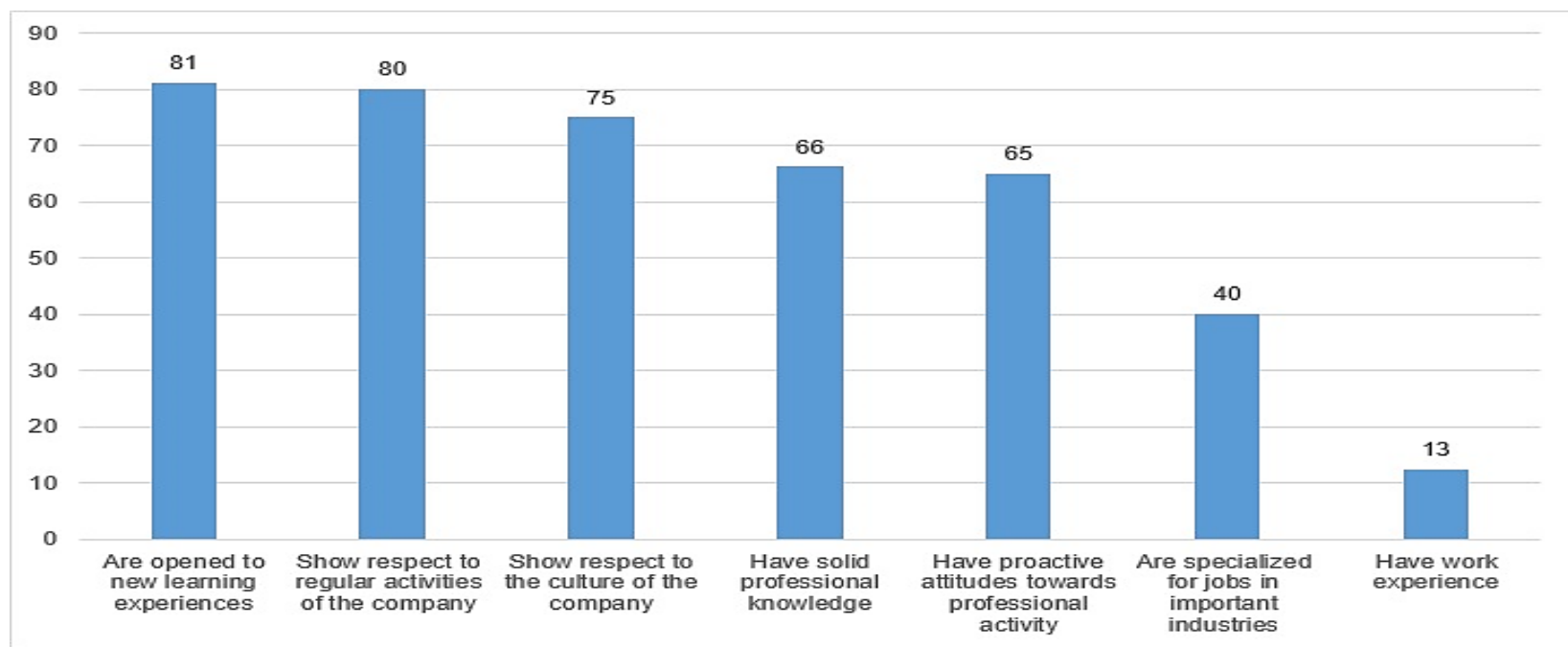

Figure 3. Employers' opinion regarding ASE graduates

Source: Authors' own research.

There are two criteria that ASE graduates meet less (below the average). Only $40 \%$ of respondents considered that ASE graduates are specialized in the most important industries and only $13 \%$ of respondents considered that ASE graduates have work experience in economic field.

Among "Other" criteria, respondents have mentioned other characteristics that were included in two categories: positive and negative characteristics (Table 2).

Table 2. Other characteristics of ASE graduates in employers' opinion

\begin{tabular}{|l|l|}
\hline \multicolumn{1}{|c|}{ Positive } & \multicolumn{1}{c|}{ Negative } \\
\hline Enthusiasm & Not able to make oral presentations \\
\hline Desire to know and become a better person & Not able to make concrete situation analysis \\
\hline Motivation & Are over-evaluated \\
\hline Practical & Without practical thinking \\
\hline $\begin{array}{l}\text { Those who have studied in a foreign language are } \\
\text { fluent in speaking, reading and writing in that } \\
\text { language }\end{array}$ & $\begin{array}{l}\text { Without the patience to follow all steps of a process and to } \\
\text { gain relevant experience. They want all NOW. }\end{array}$ \\
\hline
\end{tabular}

Source: Authors' own contribution.

Employers were asked to mention types of services that university should provide to students to increase their employability. The answers are presented below (Figure 4). 


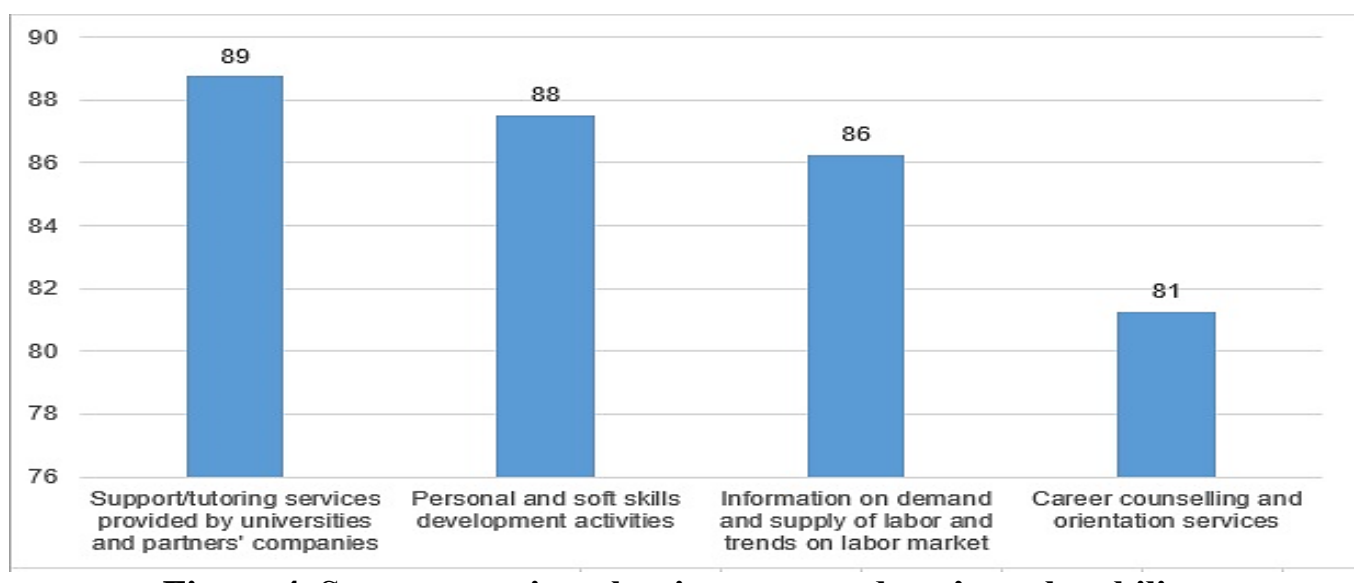

Figure 4. Support services that increase students' employability

Source: Authors' own research.

From employers' perspective the most important service is students' tutoring provided in partnership with firms and companies. Such services should be provided together with personal and soft skills development activities.

Among "Other" services, respondents have mentioned alternative career paths, internships, workshops, online counselling, networking and online communication.

\section{Conclusion}

Nowadays, employers are reconsidering the definitions of professionalism and professionals. In addition to job related knowledge and skills, a professional need some general behavioral skills too, which are especially required when working with others.

These inter-relational skills are not "hard skills", but "soft skills" or qualities and traits that enhance people interactions. Soft skills are personality traits related with character, teamwork, communication, and work ethic. Ethical behavior is the "old-fashioned skill" that experts are emphasizing nowadays. The idea of ethical behavior is not a new one: it comes from ancient time when philosophers like Aristotle and moralists discussed virtues, virtuous life, virtuous individuals and societies in relationships with the happiness. Currently, employers have a different perspective on professionalism and professionals and have specific requirements for employees to behave ethically.

The need for ethical behavior is widely accepted not only by employers, but by employees too. Employees understand that, for example, when working with others a person need to show respect or must get along well with all the people with whom they interact and communicate. Employers understand the negative consequences of unethical behaviors both at individual level and organizational level. They speak not only about negative image of organization, but also about the efficiency decrease in economic results and, even worse, bankruptcy.

The results of research on Romanian employers' perceptions on academic curriculum are consistent with the conclusions of similar research conducted in other countries and presented above. Employers appreciate graduates professionally competent, but also with strong personality and character, ethical behaviors, responsible, committed to work, capable to work in team, details oriented, and willing and being able to learn more and to develop themselves professionally.

Despite general impression that work experience is important in order to find a job, employers appreciate more graduates who can demonstrate soft skills such as communication and 
team work, or proactive attitude toward work. Digital competences and reading writing and speaking in a modern language are appreciated too.

ASE graduates are appreciated by the employers because they are open to new learning experiences, show respect to current activities conducting in the company and to organizational culture, have good knowledge and proactive attitudes toward professional activity. In the same time, employers consider that ASE graduates are well prepared theoretically or in general, but have limited practical experience.

Employers' recommendations to university aim to increase the weight of practical or work experience stages in the curriculum, to work together with employers and involve practitioners from business sector in teaching activities.

\section{References}

Blessinger, P., Sengupta, E., \& Makhanya, M. (2018). Higher education's key role in sustaiable development. Retrieved March 20, 2020, from https://www.universityworldnews.com/ post.php?story $=20180905082834986$.

Bratianu, C., Hadad, S., Bejinaru, R. (2020). Paradigm Shift in Business Education: A Competence-Based Approach. Sustainability 2020, 12, 1348; doi: 10.3390/su12041348.

Chhinzer, N., \& Russo, A. (2018). An exploration of employer perceptions of graduate student employability. Education + Training, 60(1), 104-120.

Clarke, M. (2017). Rethinking graduate employability: the role of capital, individual atributes and context. Studies in Higher Education, 1-16.

Crebert, G., Bates, M., Bell, B., Carol-Joy, P., \& Cragnolini, V. (2007). Developing generic skills at university, during work placement in employment: gradutes' perception. Higher Education Research \& Development, 23(2), 147-165.

Finch, D. J., Hamilton, L. K., Baldwin, R., \& Zehner, M. (2013). An exploratory study of factors affecting undergraduate employability. Education + Training, 55(7), 681-704.

Griffin, M., \& Coelhoso, P. (2018). Business students' persoectives on employability skills post intership experience: Lessons from the UAE. Higher Education, Skills and Work-Based Learning.

Hesketh, A. (2000). Recruting on Elite? Employers' perceptions of graduate education and training. Journal of Education and Work, 13(3), 245-271.

Moorea, T., \& Morton, J. (2015). The myth of job readiness? Written communication, employability and the 'skill gap' in higher education. Studies in Higher Education, 1-19.

Staiculescu, C., \& Richiteanu Nastase, E. R. (2018). University dropout: Causes and solution. Mental Health Global Challanges XXI Century, Conference Proceedings, 1-7. Retrieved from http://www.mhgcj.org/index.php/MHGCJ/article/view/29/22 on 09 December 2019.

Suarta, I.M. (2010). Supervisors' Perceptions of the Employability Skills Needed by Higher Vocational Education Graduates to be Successful in the Workplace. Paper presented at $14^{\text {th }}$ UNESCO APEID International Conference Education for Human Resource Development, Thailand.

Succi, C., \& Canovi, M. (2019). Soft skills to enhance graduate employability: comparing students and employers' perceptions. Studies in Higher Education, 1-14.

Wickramasinghe, V., \& Perera, L. (2010). Graduates's university lecturers' and employers' perceptions towards employability skills. Education + Training, 52(3), 226-244. 